\title{
THE ROLE OF POSYANDU IN HEALTH SERVICES FOR PREGNANT WOMEN
}

\author{
Sari Hayuningtyas, Adang Bachtiar, Afrina Sitohang, \\ Mery Aderita, Yayah Fazriyah, Febi Susanti
}

Masters Program in Public Health, Faculty of Public Health, Universitas Indonesia

\begin{abstract}
Background: Maternal and child health is a major public health concern in Indonesia. The current estimated maternal mortality rate (MMR) is 359 deaths per 100,000 live births. Some of the factors contributing to it are poor access to health care and shortage of health care provider in the community. To overcome it the government initiated the integrated health service post called integrated health service (Posyandu). Posyandu is a strategy to reduce infant or child mortality and birth rates. Posyandu aims to increase the availability and accessibility of health care. Organized by the community through the members of the Family Welfare Movement, Posyandu appears to be an important part of community welfare activities. This study aimed to determine the role of Posyandu in health services for pregnant women.
\end{abstract}

Subjects and Method: This was a qualitative study conducted in Bekasi, West Java. The subjects for this study were pregnant women, Posyandu volunteers, health service providers, and head of Posyandu. The dependent variable was health services for pregnant women. The data were collected by in depth interview, focus group discussion, and observation. The data were analyzed descriptively.

Results: Posyandu used a 5 table system service method that involved health workers and health cadres. Health services for pregnant women included health check by midwives and counseling by health cadres. Pregnant women who came to Posyandu carried a maternal and child health book. Pregnant women who did not come to Posyandu would be visited by health cadres. There were limited space for Posyandu and incomplete teaching aids available at Posyandu.

Conclusion: The role of Posyandu is positive and active in the provision of health services for pregnant mothers and children.

Keywords: pregnant woman, integrated health services

\section{Correspondence:}

Sari Hayuningtyas. Masters Program in Public Health, Faculty of Public Health, Universitas Indonesia, Depok. Email: sari.hayuningtyas@ui.ac.id.

Mobile: 08158169626.

\begin{tabular}{l}
\hline BACKGROUND \\
The maternal mortality rate (MMR) is \\
one of the important indicators used \\
to assess the health status of a nation \\
or country. MMR is the number of \\
maternal deaths during pregnancy, \\
childbirth and childbirth caused by \\
pregnancy, childbirth and childbirth, \\
or management, but not for other rea- \\
sons such as accidents or falls, in
\end{tabular}

every 100,000 live births. MMR in Indonesia is still quite high, the 2012 Indonesian Demographic and Health Survey Application (SDKI) shows that MMR in Indonesia is 359 per 100,000 live births (Indonesian Health Profile in 2016). Some of the factors that contribute to it are poor access to health care and a shortage of health care providers in the community. 
To overcome maternal health problems a comprehensive and integrated effort is needed to improve the quality of maternal health services through optimization of programs, policies, cross-sectorial role and the role of Community-Based Health Efforts (UKBM), so that the government initiates integrated health service posts called Posyandu. Posyandu is a strategy to reduce maternal and infant mortality. Posyandu is one form of UKBM that is managed and organized from, by, for and with the community in the implementation of health development, in order to empower the community and provide facilities to the community in obtaining basic health services, to accelerate the reduction of maternal and infant mortality. (Ministry of Health, 2011).

Posyandu conducts basic health services aimed at infants, toddler children, pregnant women and postpartum, fertile age couples (PUS), whose activities include at least 5 activities namely maternal and child health (KIA), family planning (KB), immunization, nutrition services, and management of diarrhea. Health services for pregnant women carried out included weighing of body weight and height measurements, blood pressure measurements, monitoring of nutritional status, administration of iron tablets, administration of Tetanus Toxoid (TT) immunization, fundus uterine examination, counseling, labor planning and prevention of complications $\left(\mathrm{P}_{4} \mathrm{~K}\right)$ and post-natal birth control carried out by health workers assisted by cadres.

Posyandu is held once a month, where for the selected day and time, according to the results of the agreement. If needed, the implementation day of the Posyandu can be more than once a month (Ministry of Health, 2014).

Posyandu is held directly by Posyandu cadres. Posyandu cadres are community members who are willing, able and have the time to organize Posyandu activities voluntarily. In carrying out their duties, the cadres are assisted by health workers to provide services that are not possible for cadres such as immunization vaccine injections, and pregnancy examinations. In the implementation of the Posyandu, a 5-table system is used where 4 tables are managed by cadres, and the fifth table is managed by health workers (Ministry of Health, 2011).

The number of active Posyandu in Indonesia is 164,867 Posyandu from a total of 291,447 Posyandu, or around $56.57 \%$ (Ministry of Health, 2017). The number of Posyandu in West Java Province in 2016 was 51,035 Posyandu, where the city of Bekasi had the highest ratio of adequate Posyandu to the existing community, namely 1/27,71 (Profil Kesehatan Jawa Barat, 2016).

Several related studies on Posyandu have been conducted, among others, Saepudin states that Posyandu has an important role in improving the quality of maternal and child health through the health service process, and Posyandu has become a public health information center (Saepudin, 2017). Although there are several studies that state Posyandu is quite effective, there are still contradictory studies. Among others, the Aditya's 
(2015), shows that there are limited facilities and infrastructure to support the implementation of Posyandu, resulting in dissatisfaction with Posyandu users.

Several factors related to the implementation of Posyandu included the age of cadres, cadre education level, length of time as cadre, provision of counseling media, cadre training, cadre training, motivation, facilities and infrastructure, involvement of cross-sector roles, provision of information and communication (Khomsah, 2012; Rahayu, 2001).

Therefore, looking at the above problems, research needs to be done to determine the role of Posyandu in the health services for pregnant women.

\section{SUBJECTS AND METHOD
1. Study Design}

This was a qualitative study conducted at Posyandu in Bekasi City, West Java in April 2018.

\section{Study Informants}

Informants in this study were pregnant women, Posyandu cadres, and health workers from the community health center. The informant selection technique by purposive sampling. In addition, data sources are obtained from the results of observations. The dependent variable in this study is health care for pregnant women.

\section{Data Collection Technique and Analysis}

The data were obtained using indepth interviews, focus group discussions and observations. The technique of analyzing data is data collection, presentation, reduction, collection, and conclusions.

\section{RESULTS}

\section{Characteristics of Informants}

This research was conducted on informants with the characteristics of pregnant women who came to the Posyandu, cadres, and midwives as health workers for the Posyandu. For the validity of the results, the study carried out triangulation of data and sources and methods by comparing the results of interviews, Focus Group Discussion (FGD), observation, information obtained from informants and observations.

\section{Material factor \\ a. Financing}

From the FGD activities and in-depth interviews that have been conducted, it is known that the funding or funds for the implementation of the Posyandu are from self-help cadres, while the additional costs come from voluntary contributions from Posyandu visitors. Funds for financing Posyandu are still very lacking. Funding for Posyandu can come from various sources, such as the government, the private sector, the community, as a result of the efforts of the Posyandu implements (Ministry of Health, 2011). It also found a lack of support from local stakeholders so that the Posyandu had not been able to find a solution to the financing problem, according to the informants' opinion as follows: "self-help, from cadres and my own personal", and "health funds do not exist".

\section{b. Counseling kit}

The results showed that there was no counseling's kit at the Posyandu. The outreach, media originating from a community health center (puskesmas) and the village are only used 
when there are counseling events outside the Posyandu activities. This is in accordance with the opinion of the informant: "what is it ..., there is no counseling media, we only deliver it verbally ... for example, we already weighed the mother who arrived, then we gave counseling for nutrition".

\section{c. KIA book}

The results showed that some informants knew about the book of Maternal and Child Health (KIA book) and that it was important to take the KIA book to the Posyandu, the contents of the KIA books were also explained during the visit. Usually cadres or health workers remind to bring KIA books. But there were informants who did not know what the KIA book was, along with the informants' opinion "The Posyandu participants on average carry KIA books ..." and also "The KIA books do not carry and do not know their functions".

\section{Machine factor}

Based on the results of the research there are basic facilities that must be equipped so that health services can run optimally. The results of observations, FGDs and interviews with health workers and cadres, showed that the basic facilities not yet available at the Nangka Posyandu have been LILA bands (upper arm circumference), Information and Education Communication materials (IEC), Doppler devices.

This is in accordance with the informant's dialogue, namely "I don't have a Doppler check for pregnan$c y "$. Whereas the facilities that are still lacking are beds for pregnant women who are still borrowing beds be- longing to cadres. The location of the Posyandu is affordable on foot and quite strategic, according to the informant's statement "the location of the Posyandu is close to my house".

However, the Posyandu is less extensive to accommodate all visitors to the Posyandu. This is in accordance with previous research regarding factors that influence the motivation of pregnant women to visit Posyandu, including knowledge of pregnant women and the ease of reaching Posyandu (Rahayu, 2001). Accessible and affordable Posyandu locations are one of the influencing factors. The place for organizing a Posyandu can be carried out using residents' houses, yard, market, office space, or buildings that are established independently by the community (Ministry of Health, 2014).

\section{Measurement factor}

From the results of the research by interviewing, observing and reviewing the Posyandu report document, the implementation of the Posyandu was carried out regularly 1 day, every month with a 5 -table system, cadres actively served and had great motivation to provide services to pregnant women. Table 1 is registration carried out by cadres, table 2 is weighing by cadres, table 3 is filling in KIA books by cadres, table 4 is counseling by cadres, while table 5 is a health services carried out by health workers assisted by cadres.

\section{Man factor}

\section{a. Posyandu cadres}

From the results of the Focus Group Discussion participants' opinions, indepth interviews and observations on the role of Posyandu cadres and moti- 
vation as Posyandu cadres, most informants said that active cadres in the service were guided, aware and implemented system 5 tables and there was already a division of tasks at the Posyandu. The following are some statements from informants: "Cadres are in accordance with the tasks ..., there are task arrangements and rolling, each cadre understands service at 5 tables" and "for me... $i$ can be a cadre, $i$ can help people. Yes, I want to help".

The number of cadres present was 10 people, meaning that it exceeded the standard of at least 5 people according to the Posyandu general management book.

\section{b. Health workers}

From the results of the FGD and indepth interviews, health workers were present at each Posyandu implementation and provided health services at table 5 such as examining pregnant women and immunization.

However, according to some informants, health workers have not optimally provided guidance and knowledge to the cadres, along with a number of informants' statements regarding health workers "actually good ... but she seemed like not giving directions ...", "yeah ... she's good, ma'am, checking on pregnant women", and "I am ready to provide and prepare vaccines according to the target number and provide services to pregnant women".

Knowledge is the dominant factor that relates to the role of cadres in the Posyandu, so it is expected that health workers can help increase cadre's knowledge (Nurlatifah, 2015).

\section{Method factor}

a. System 5 table

From the FGD activities, in-depth interviews and observations made were known that the 5 -table system had been implemented at the Posyandu. The 5-table system consists of registration, weighing, recording, counseling and service. Active cadres assisted with the implementation of the Posyandu, there were 10 cadres present. The midwife 1 person from the puskesmas who is the regional supervisor is also present to provide services at the Posyandu.

\section{b. Program outside Posyandu} schedule

From the FGD activities, in-depth interviews, and observations made, it was known that there was no specific program, but for some informants the activity of visiting pregnant women who did not come to the Posyandu was considered a program outside the Posyandu schedule. Usually cadres go around to visit pregnant women who do not come to the Posyandu, at that time weighing, recording and counseling are carried out and motivating pregnant women to come to the Posyandu.

This is in accordance with the cadre's duties outside the opening days of the Posyandu, which is to follow up on targets who do not come to the Posyandu or targets that need further counseling (Ministry of Health, 2011).

\section{Measurement factor}

Based on the results of interviews and observations, the Posyandu lacked the support of the relevant stakeholders, especially funding and there were no administrative documents for the 
Posyandu operational working group (pokjanal) in the area, along with the information conveyed: "We have letters of cadres' names but not letters of pokjanal. We are not supported ". Policies regarding the implementation of Posyandu have been regulated by the Ministry of Internal Affairs, Minister of Home Affairs Regulation Number 54 of 2007 concerning Guidelines for Establishing an Operational Working Group for the Development of Integrated Service Posts. In the regulation, it is very clear that the tasks and functions of the Pokjanal are from the provincial level to the village. One of the pokjanal's tasks is to develop an activity plan and seek funding sources to support the activities of the Posyandu (Permendagri No. 54 of 2007).

Of the five factors, in general the implementation of Posyandu has gone quite well, even though there are still shortcomings that need to be improved to optimize health services for pregnant women, as in the lack of material/ financing factors, counseling kit media facilities are not yet available.

The machine factor is still incomplete, for example, there are no Doppler devices, pregnant women's check beds, and limited Posyandu room space.

Man factor is good enough where active cadres carry out their duties but need guidance on knowledge and direction from health workers, health workers need to be more intensive in increasing cadre knowledge.

The method factor is implemented with a 5 -table system, this is in accordance with the general management guidelines of the Posyandu.

The measurement factor has not been full support from stakeholders for funding and the absence of a Pokjanal decision letter as an administrative completeness of the Posyandu.

\begin{tabular}{r}
\hline REFFERENCE \\
\hline Aditya $\mathrm{T}$ (2017). Analisis kualitas \\
pelayanan Posyandu Camar \\
Kelurahan Poris Plawad Utara \\
Kecamatan Cipondoh Kota Ta- \\
ngerang. Journal of Govern- \\
ment and Society, 1(2). \\
Effendie EN (2015). Faktor-faktor
\end{tabular}
yang berhubungan dengan peran kader di Posyandu Mandiri UPT Puskesmas Sindangjaya Kecamatan Mandalajati Kota Bandung tahun 2015. Depok: Fakultas Kesehatan Masyarakat, Universitas Indonesia.

Health Office Bekasi (2015). Profil kesehatan Kota Bekasi Tahun 2014. Bekasi: Dinas Kesehatan Kota Bekasi.

Khomsah N (2012). Faktor-faktor yang mempengaruhi peran serta kader Posyandu dalam deteksi faktor resiko ibu hamil di wilayah kerja puskesmas Buayan Kebumen Jawa Tengah. Depok: Fakultas Kesehatan Masyarakat, Universitas Indonesia.

Martha E, Kresno S (2016). Metodelogi penelitian kualitatif. Jakarta: Penerbit PT Rajagrafindo Persada.

Ministry of Health (2011). Pedoman umum pengelolaan Posyandu. Jakarta: Kementerian Kese- 
hatan RI.

Ministry of Health (2014). Buku saku pegangan kader Posyandu. Jakarta: Kementerian Kesehatan RI.

Ministry of Health (2017). Profil kesehatan Indonesia 2016. Jakarta: Pusat Data dan Informasi, 2017.

Ministry of Home Affairs (2007). Minister of Home Affairs Regulation No. 54 of 2007 concerning Guidelines for Establishing an Operational Working Group for the Development of Integrated Service Posts Jakarta: Ministry of Home
Affairs Republic of Indonesia.

Rahayu S (2001). Faktor-faktor yang mempengaruhi motivasi ibu hamil dalam memanfaatkan Posyandu. Depok: Fakultas Ilmu Keperawatan, Universitas Indonesia.

Saepudin E, Rizal E, Rusman A (2017). Peran Posyandu sebagai pusat informasi kesehatan ibu dan anak. Record and Library Journal, 3(2).

Wahyuni N (2016). Posyandu: upaya peningkatan kesehatan ibu dan anak. Depok: Fakultas Ilmu Budaya, Universitas Indonesia. 